\section{The Thalassemia International Federation: a global public health paradigm}

\author{
Elpidoforos S. Soteriades, ${ }^{1,2}$ \\ David Weatherall ${ }^{3}$
}

${ }^{1}$ Department of Occupational and Environmental Medicine, Cyprus Institute of Biomedical Sciences (CIBS), Nicosia, Cyprus; ${ }^{2}$ Department of Environmental Health, Environmental and Occupational Medicine and Epidemiology (EOME), Harvard School of Public Health, Boston, MA, USA; ${ }^{3}$ Weatherall Institute of Molecular Medicine, University of Oxford, John Radcliffe Hospital, Oxford, UK

\begin{abstract}
Many international organizations are struggling today to coordinate limited economic and human resources in support of governments' efforts to advance public health around the world. The United Nations and the World Health Organization, along with others play a pivotal role in this global effort. Furthermore, during the past few decades an increasingly higher percentage of global efforts on public health are carried out by specific health initiatives, international projects and non-governmental patient-oriented organizations. The Thalassemia International Federation (TIF) is one such organization focusing on the control of thalassemia around the world. The current paper aims at presenting a comprehensive overview of the mission, goals, objectives and activities of this organization. Our ultimate goal is to highlight TIF's public health paradigm and diffuse its success at an international levels for others to follow. TIF is devoted to disseminating information, knowledge, experience and best practices around the world to empower patients with thalassemia and their relatives, support health professionals providing care to such patients and promote national and international policies, which secure equal access to quality care for all patients with thalassemia.
\end{abstract}

\section{Introduction}

Improving global health remains the target of many international and non-governmental organizations around the world struggling to coordinate limited economic and human resources often among conflicting interests in order to promote economic and social development, strengthen global security and enhance the health of our societies. The collective work of the nations focusing on health is coordinated through the United Nations (UN) along with the World Health Organization (WHO) and its regional offices. WHO maintains a central role in promoting global health and advancing several health priorities on the national, regional and global level by directing or coordinating international health projects, promoting health policies and providing technical assistance to different countries. The World Bank along with other organizations within the UN is focusing much of their efforts on specific public health issues. Such organizations include the United Nation Children's Fund (UNICEF) and the United Nation Development Program (UNDP). Additional agencies include the United States Agency for International Development (USAID), the European Council Development Program (EC), the United States Centers for Disease Control and Prevention (US CDC) and the European Center for Disease Prevention and Control (ECDC). Non-governmental organizations such as the International Committee of the Red Cross are becoming increasingly important in the sphere of global humanitarian efforts including international health crises.

However, promoting global health and achieving measurable outcomes on a global scale remains a far reaching goal and constitutes a complicated agenda in a world of continued storms caused by wars, famine, natural disasters, and mass population displacements. Apart from the above international organizations, during the past few decades, the work of global health initiatives and international projects has become increasingly important, since they contribute a considerable portion of funds devoted to global health. Such work requires enormous support from grass root organizations around the world in order to offer meaningful results at the population level. A successful paradigm of an international non-governmental grass root patient-oriented organization focusing on a specific health issue is the Thalassemia International Federation (TIF).

An important global health issue, hemoglobinopathies are the commonest single gene disorders among all clinically important hereditary disorders around the world. ${ }^{1,2}$ Thalassemias, the most important of which are the $\alpha$ - and $\beta$-thalassemias, have received particular attention in the past decades and continue to attract strong interest from clinicians, public health professionals and policy makers due to their clinical, social and economic sig-

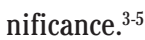

The objective of our current paper is to present a comprehensive overview of the mission, goals, objectives and activities of TIF aiming to distribute information and knowledge on the prevention and treatment of thalassemia and
Correspondence: Elpidoforos S. Soteriades, Cyprus Institute of Biomedical Sciences (CIBS), Athienitis Strovolos Park, $2^{\text {a }}$ Elia Venezi St. Office 206, 2042 Strovolos, Nicosia, Cyprus.

Tel. +357.99410677 - Fax: +357.22499420.

E-mail: esoteria@hsph.harvard.edu

Key words: epidemiology, thalassemia, TIF, public health, global health.

Acknowledgements: the authors would like to thank Dr. Androulla Eleftheriou and Dr. Michael Angastiniotis for their valuable help and support in writing this manuscript. They would also like to thank Mrs. Liz Rose for her invaluable assistance and secretarial work.

Contributions: ESS conceived of the idea for the study and gathered the information needed. ES and DW wrote the preliminary draft of the manuscript. Both authors contributed to the final version of the manuscript. Both authors read and approved of the final version of the manuscript.

Conflict of interests: the authors declare that they have no competing interests.

Received for publication: 26 July 2013

Revision received: 21 February 2014.

Accepted for publication: 19 March 2014.

This work is licensed under a Creative Commons Attribution 3.0 License (by-nc 3.0).

@C Copyright E.S. Soteriades and D. Weatherall, 2014 Licensee PAGEPress, Italy

Thalassemia Reports 2014; 4:1840

doi:10.4081/thal.2014.1840

hemoglobinopathies in order to help patients and their families and also support health professionals in reducing the overall public health burden of these hereditary disorders around the world.

\section{Establishment of Thalassemia International Federation}

Thalassemia constituted a grave problem in the past, and was most prevalent in countries where malaria was formerly prevalent or still remains a health issue, as a result of the genetic advantage of the carriers over the malaria infection. Countries with high prevalence of thalassemia such as Cyprus, ${ }^{6,7}$ Greece, ${ }^{8,9}$ Italy, ${ }^{10,11}$ and others initiated national prevention and control programs in the early 70 s, leading consequently to drastic reductions in the number of affected births. Such considerable improvements in the preventive efforts spared valuable societal resources ${ }^{12}$ that were devoted for improved clinical care for existing thalassemia patients resulting in prolonged 
survival rates and improved quality of life. However, the above achievements for many years were only materialized in Southern Europe and some parts of North America. National support associations in countries with high disease prevalence had advocated for improved patients services with considerable success. Once the high number of patients with thalassemia and the lack of prevention programs in other countries and continents were noted, it was realized that the case of thalassemia in the world was far from closed. By the early 1980s considerable progress had been made on various aspects of the thalassemia problem. ${ }^{5}$ The pathophysiology of the disease was broadly understood, and its mode of inheritance and methods for detecting carriers had been clearly defined. A start had also been made in defining the variety of different mutations involved in the hemoglobin genes. And by fetal blood sampling and measuring the rates of globin chain synthesis over 5000 prenatal diagnoses had been reported from 12 different countries. A start had also been made in making a fetal diagnosis by DNA analysis, the DNA being obtained much earlier in pregnancy by chorion villus sampling. By that time there was also clear evidence that severe forms of thalassemia could be controlled by adequate transfusion combined with the clearly defined use of chelating agents. These issues were summarized together with a discussion of the broader community problems of the thalassemias by the WHO Working Group on the Community Control of Hereditary Anemias chaired by one of us (DJW) in $1982 .{ }^{13}$ This meeting was attended by many of those who had been involved in developing the field including Antonio Cao, Bernadette Modell, Prawase Wasi, Dimitris Loukopoulos and many others. At this meeting, as well as summarizing progress in prevention and management of the thalassemias and related diseases, the importance of its social issues relating particularly to better support and education for families and the potential value of partnerships between centers in the richer countries and those in some of the developing countries was discussed. It was undoubtedly the results of the report of this meeting that stimulated thinking about how improvements could be developed in the community aspects of the thalassemias.

Therefore, in 1986, patients with thalassemia and their families mainly from England, Italy, Greece, Cyprus, and the USA met in Milan, Italy to discuss the possibility of collaboration for this global issue. It was during this meeting that a strong urge to support patients with thalassemia around the world was strongly expressed and hence the birth of TIF; an international patients/parents organization serving as an official body to ensure the rights of patients for quality health care while at the same time promoting prevention and control programs. Many patients and parents volunteered to provide support and the Thalassemia International Federation, was officially registered in 1987 as a non-profit non-governmental organization with its headquarters established in Nicosia, Cyprus. A blood drop was chosen as the logo of the organization symbolizing the blood needed to give life to patients with thalassemia (Figure 1).

\section{Organizational structure of Thalassemia International Federation}

The Thalassemia International Federation is established as a non-profit, non-governmental patient-driven organization. It is registered under Cyprus Company Law Cap.113, as a limited liability company (non-profit organization). TIF maintains its headquarters in Nicosia, Cyprus, including offices serving as the global information distribution center, the administrative base of the federation, and a conference center hosting board meetings and educational events.

The Federation is governed today by an 18member international Board of Directors with balanced geographical coverage, elected for a term of 4 years. The Board of Directors has 2 non-country affiliated members elected for their excellence in contribution at the national/international level and 16 country members proposed by their corresponding national patients' associations (TIF voting members). According to TIF's Constitution, one country can be represented with a maximum of 2 members and $50 \%$ of its Board of Directors must include patients with thalassemia (Figure 2).

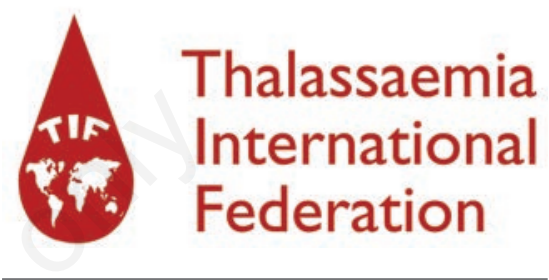

Figure 1. The logo of the Thalassemia International Federation (TIF).

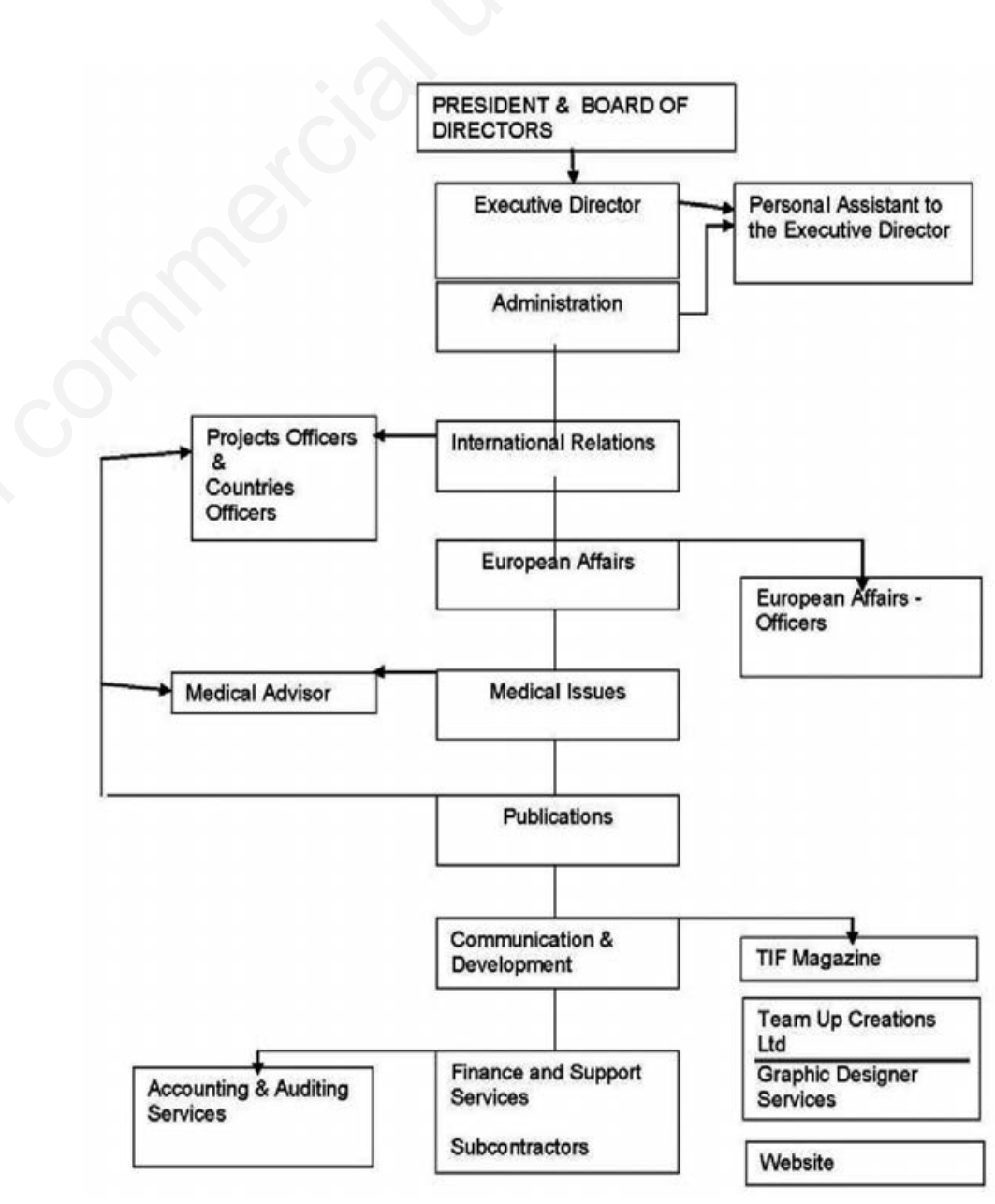

Figure 2. Thalassemia International Federation organizational chart. 
The Board meets twice a year and exercises control over the finances, strategy and activities of the Federation. It is responsible for the main functions of the headquarters' office, which is staffed today with 10 employees on a permanent basis and a number of others on a contractual basis.

TIF members comprise of two main membership categories, the General and Voting Members, which include only Hemoglobinopathy Patients' Associations. A third category of membership is the Associate members, which may include health professional associations, individuals involved with hemoglobinopathies and industry. Any general member is eligible to become a voting member with the right to vote and be voted at the General Meetings every four years, where the new Board is elected and financial/policy issues are approved by the General Assembly. Currently, TIF has 60 general and 50 voting members (110 members) from 60 different countries across all six WHO regions [South-East Asia Region (SEAR0), Americas Region (AMR0), Western Pacific Region (WPRO), Eastern Mediterranean Region (EMR0), African Region (AFRO) and European Region (EUR0)] as shown in Table 1.

\section{Mission, goals and objectives of Thalassemia International Federation}

TIF was founded with an ambitious vision to help ensure equal access to quality health care for every patient with thalassemia and other hemoglobin disorders around the world. The mission of the organization is viewed as the development and establishment of National Programs for the prevention and management of hemoglobinopathies in all affected countries. The main goals and objectives of TIF set forth in order to achieve its mission include:

- The empowerment of patients and their families through the development of patients' support groups and strengthening of their voice and capacity to work and ensure the necessary medical, public health, economic, social and cultural support. ${ }^{14}$

- The promotion of recommendations and resolutions ${ }^{15,16}$ at the national and international to prioritize and integrate hemoglobin disorders into WHO and EU programs on Non Communicable Diseases, Birth Defects, and Rare Diseases. Empowerment is closely associated with this objective envisioning an active role in the policy arena.

- The generation and dissemination of reliable, evidence-based and updated information and knowledge on hemoglobinopathies for medical practitioners, nurses, other public health professionals, patients' organizations and the community at large.

- The development of productive collaborations with other organizations, health professionals, national and international bodies, regulatory agencies, industry, and other disease-oriented organizations focusing on the establishment of networks of academic and public health institutions, expert cen- ters and health professionals to support its work and mainly its educational programs.

- The solid commitment of TIF to promote patients' rights, equitable access to quality care, and provision of a holistic care approach including medical, psychological and social services, as well as support of active partnerships and productive dialogues with all stakeholders. ${ }^{17}$

- TIF's core scope is to act as the global united voice of patients with hemoglobinopathies and particularly for patients with thalassemia.

\section{Thalassemia International Federation: activities, milestones and highlighted achievements}

In the context of the above described goals and objectives, TIF has developed many different programs and services and has experienced many successes over the past 25 years of its operation.

\section{Awareness on hemoglobinopathies}

The international community, with the contribution of TIF, has adopted in 1993 the $8^{\text {th }}$ of May as the Official International Thalassemia Day. This special day every year constitutes an important opportunity for TIF to focus on a different theme in order to commemorate patients with thalassemia, who are no longer

Table 1. Members of Thalassemia International Federation by World Health Organization regions.

\begin{tabular}{|c|c|c|c|c|c|}
\hline $\begin{array}{l}\text { African Region } \\
\text { (AFRO) }\end{array}$ & $\begin{array}{l}\text { Americas Region } \\
\text { (AMRO) }\end{array}$ & $\begin{array}{l}\text { Eastern Mediterranean } \\
\text { Region (EMRO) }\end{array}$ & $\begin{array}{l}\text { European Region } \\
\text { (EURO) }\end{array}$ & $\begin{array}{l}\text { South-East Asia Region } \\
\text { (SEARO) }\end{array}$ & $\begin{array}{l}\text { Western Pacific Region } \\
\text { (WPRO) }\end{array}$ \\
\hline $\begin{array}{l}\text { Algeria } \\
\text { Mauritius } \\
\text { South Africa }\end{array}$ & $\begin{array}{l}\text { Argentina } \\
\text { Canada } \\
\text { Trinidad and Tobago } \\
\text { USA }\end{array}$ & $\begin{array}{l}\text { Afghanistan } \\
\text { Bahrain } \\
\text { Egypt } \\
\text { Iran } \\
\text { Iraq } \\
\text { Jordan } \\
\text { Lebanon } \\
\text { Morocco } \\
\text { Oman } \\
\text { Pakistan } \\
\text { (State of Palestine) } \\
\text { Saudi Arabia } \\
\text { Sudan } \\
\text { Syrian Arab Republic } \\
\text { Tunisia } \\
\text { United Arab Emirates } \\
\text { Yemen }\end{array}$ & $\begin{array}{l}\text { Albania } \\
\text { Azerbaijan } \\
\text { Belgium } \\
\text { Bulgaria } \\
\text { Cyprus* } \\
\text { Denmark } \\
\text { Finland } \\
\text { France* } \\
\text { Germany } \\
\text { Greece* } \\
\text { Israel } \\
\text { Italy* } \\
\text { Luxembourg } \\
\text { Malta* } \\
\text { Netherlands } \\
\text { Portugal } \\
\text { Romania } \\
\text { Spain } \\
\text { Switzerland } \\
\text { Turkey } \\
\text { United Kingdom* }\end{array}$ & $\begin{array}{l}\text { Bangladesh } \\
\text { India } \\
\text { Indonesia } \\
\text { Maldives } \\
\text { Nepal } \\
\text { Sri Lanka } \\
\text { Thailand }\end{array}$ & $\begin{array}{l}\text { Australia } \\
\text { Cambodia } \\
\text { China (PRC) } \\
\text { Malaysia } \\
\text { Philippines } \\
\text { Singapore } \\
\text { Taiwan (ROC) } \\
\text { Vietnam }\end{array}$ \\
\hline 3 & 4 & 17 & 21 & 7 & 8 \\
\hline
\end{tabular}

\footnotetext{
*Countries that maintain a national registry for patients with $\beta$-thalassemia.
} 
with us, but also to help all those patients who are fighting everyday for their right for a better quality of life. TIF also uses this opportunity to bring about awareness on special issues related to patients with Hemoglobin disorders. The 2013 theme was dedicated to thalassemia intermedia and TIF invited all national thalassemia associations across the world as well as other patient support groups to improve their knowledge and understanding on this particular disease variant.

TIF started publishing a Quarterly magazine in 1998 focused on providing scientific, regulatory, social and other news relevant to patients with thalassemia and their families. This is the first periodic publication, which reflects the voice of the global community on issues related to thalassemia distributed to more than 3500 recipients in 58 different countries. Since its origin, the Magazine has now reached its $61^{\text {st }}$ issue.

Since 2002, a Bimonthly electronic newsletter is also distributed to all voting and general members of the Federation providing direct updates on different fronts of TIF activities, and supplements the TIF magazine on issues requiring urgent attention or concern.

TIF has also developed and maintains its Official active website providing comprehensive, reliable and updated information mainly to the patients and their families but also to health care providers, public health professionals and the lay public regarding thalassemia and hemoglobin disorders. In addition, TIF supports other project-oriented websites such as ITHANET and ENERCA.

\section{Advocacy work}

TIF advocacy work is mainly focused on undertaking Delegation visits and field trips in different countries around the world in order to investigate the prevailing situation with regards to prevention and control programs for hemoglobin disorders, and build official networks and collaborations with the health authorities, policy makers, the medical community and the patients/parents community. TIF officials collaborate with local representatives in each country to spread disease awareness, share information and knowledge, support educational activities and develop joint plans of actions and national control programs focused on hemoglobin disorders. Since its inception, TIF officials have completed $160 \mathrm{del}$ egation visits/field trips in 60 different countries.

Another important aspect of TIF's advocacy work is the development of Position papers that promote the official position of TIF on various critical matters relevant to the thalassemia and the patients' community. Up to date, TIF officials have prepared six position papers with the following titles:

The Thalassemia International Federation's
(TIF) new focus: - addressing the management of non-transfusion-dependent thalassemias (NTDT);

Patients' rights - patients' safety - counterfeit medicines - a global threat;

The 8th of May - Theme: 'Patients rightsrevisited';

The use of ribavirin in the management of chronic viral hepatitis in thalassemia and sickle cell disease;

Chronic hepatitis $C$ in transfusion depended thalassemia; and

The view of the Global Patient Community.

\section{Educational programs}

TIF is heavily involved in the organization of Seminars, Workshops, and Conferences at the national, regional and international level with target audiences ranging from medical specialists, nurses, public health professionals, policy makers and other scientists and lay people acknowledging the multidisciplinary approach for the management of these disorders including the active involvement of patients and their families. TIF's work is highlighted by the 15 training seminars, the 55 national workshops, the 10 regional conferences and workshops and the 15 international conferences that have been organized by TIF with over 30,000 participants including health professionals, patients and their families.

TIF officials, as well as TIF's internal and external consultants have prepared, edited, published, and translated educational materials on thalassemia and hemoglobin disorders including leaflets, booklets and scientific books for medical specialists, other health professionals, patients and their families, national associations and the community at large. Three publications addressed to medical specialists, 8 publications for the patient community, 7 booklets for the community at large and 1 book for the global patient community rights have been prepared. A total of 35,000 issues of the above educational materials have been distributed to 65 countries, while $20 \%$ of the above publications have been translated in 10 different languages and 5\% in 15 languages. One of the above publications has been translated so far in 25 languages.

TIF is particularly proud for the Electronicbased Master of Science (e-MSc) course in hemoglobinopathies that has been developed in collaboration with the University College London (UCL). This is a unique opportunity for health professionals to specialize in the field of hemoglobinopathies using an online program with minimum disruption of professional and personal lives. The course was launched in collaboration with TIF to contribute to our mission of achieving equal access to quality health care for every patient with thalassemia around the world. The program offers three academic degrees on a part- time or full-time basis, for students from around the world: Master of Science - MSc (1 year, full time/2 years, part time), Diploma (8/16 months) and Certificate (4/8 months). The course objectives may be viewed online and include the following:

- To develop skills in basic and clinical science in the field of prevention, medical treatment and additional care for patients with hemoglobinopathies;

To learn about the prevention and holistic management of hemoglobinopathies as part of a multidisciplinary team;

- To analyze information and display data using different statistical methods; and

To learn methods of counseling and providing patient care, using role-play models in video conferencing programs.

The course has been designed to meet the needs of a wide range of medical professionals including physicians interested in hemoglobinopathies (general practitioners, pediatricians, hematologists, clinical geneticists, obstetricians/gynecologists, behavioral scientists); and other healthcare professionals such as counselors, clinical psychologists, nurse specialists and midwives. The course is currently suspended and is being revised and upgraded. It is expected to resume in 2014. To date 44 students from 15 countries have graduated from the above educational program.

\section{Research projects}

TIF officials and consultants coordinate a number of different research projects but also participate or contribute to several other projects initiated by international collaborators. Research projects from the past included the development of professional networks on hemoglobinopathy but also involved many aspects on the improvement of the quality of health care in a global scale. The Federation has undertaken 6 major research projects and has contributed or participated in 25 other projects.

\section{Collaborations}

TIF maintains official relations with the World Health Organization (WHO) since 1996. Such a relation entails joint activities, collaboration and participation with headquarters, regional offices, national offices and WHO collaborating centers. In addition, TIF officials cooperate closely since 1998, with the Blood Transfusion Safety Department of WHO office. To date, TIF has been represented in 15 Executive Board Meetings and World Health Assemblies, 16 regional Assembly meetings and is currently collaborating with 25 national WHO offices.

TIF also collaborates and/or is a member of other patient-oriented organizations at the national, European and international level. A list of the most important organizations with 
which TIF has close ties is given below:

- European Commission and EPHC contributing to the development of consultations, amendments, directives and regulations;

- International Alliance of Patient Organizations (IAPO);

- European Rare Diseases (Eurordis);

- European Public Health Alliance (EPHA);

- European Patient Forum (EPF);

- International Genetic Alliance (IGA);

- European Genetic Alliance (EGA);

- European Hematology Consortium (EHC);

- European Medicinal Agency (EMA): Committee for Advanced Therapy (CAT);

- Member of Patient Advisory Group of the European Health Alliance (EHA);

- In official relations with the International society of Blood Transfusion (ISBT); and

- European School of Transfusion Medicine (ESTM).

TIF also is actively focused on the establishment of official networks and collaborations with medical practitioners from different specializations relevant to the multidisciplinary approach required for the management of hemoglobinopathies: i) endocrine network; ${ }^{18,19}$ ii) liver network; iii) cardiac network; and iv) nurses network.

To date, 250 health professionals from 20 countries participate in the above networks scheduled to expand significantly to cover all world regions.

It is indeed a major milestone celebrated in the $3^{\text {rd }}$ Pan-European Conference on Hemoglobinopathies and Rare Anemias organized in Limassol Cyprus in 2012, that TIF has completed 25 years of its operations. Over its history, TIF has achieved much more. In Table 2 we delineate a summary of the most important achievements of TIF.

\section{Discussion}

In the current manuscript we have delineated the foundation and evolution of TIF over the past 25 years as well as its contribution to the prevention and control of thalassemia and other hemoglobinopathy disorders in all affected countries around the world. We have also presented the day-to-day activities of the organization as summarized in five main categories that include: i) awareness promotion for the empowerment for patients with thalassemia; ii) advocacy work for the development of policies, directives and regulations; iii) educational programs for health professionals and lay people; iv) research projects; and v) international collaborations for the advancement of its goals and objectives.

TIF's work has been eloquently described in an excerpt by Dr. George Stamatoyiannopoulos from the University of Washington - School of Medicine by saying that: TIF has done a great job in educating patients, parents and health providers around the world. No academic institution or governmental or international agency can claim a similar accomplishment. As in many other organizations, the success is attributed to hard work and productive collaboration between many dedicated, committed and highly motivated and passionate individuals from all paths of science and life. The individuals who have served on the Board of Directors since TIF's establishment, the numerous health professionals on TIF's scientific advisory panels, officials and policy makers from national governments including the government of Cyprus, patients with thalassemia from around the world, TIF's employees and many others behind the scene are only a few to mention.

In 1987, awareness, scientific knowledge, clinical experience, national and international policies and regulations, and prevention and control programs for thalassemia were at their infancy on a global level with the exception of a few pioneering countries. Twenty-five years later, the natural history of the two main hemoglobin disorders within the family of hemoglobinopthies; namely thalassemia and sickle cell disease has completely changed. From being childhood fatal disorders they have been transformed into preventable illnesses that can be reasonably managed symptomatically or even treated radically with excellent survival rates ${ }^{20,21}$ providing an extremely rewarding quality of life ${ }^{22}$ for affected patients. Appropriate national policies and adequate political commitment provides an ideal supportive environment for such patients empowering them in a sustainable fashion. Scientific knowledge and technical issues are no longer today a reason for not effectively addressing once difficult clinical challenges of the past with respect to hemoglobinopathies.

TIF has indeed made its own invaluable contribution in this journey of unprecedented advances and this publication pays respect and recognition to the first handful of patients and families, who have offered so much. Although desperate, in agony, fear, and uncertainty for the unknown and hopeless future, these unfortunate pioneers motivated themselves and believed that they could bring about change and a brighter future for themselves and their own children, by working hard to materialize their vision into a tangible hand of help for the global family of those affected. In addition, this paper, aims at paying respect and highlighting its recognition to those few medical specialists

Table 2. A summary of Thalassemia International Federation activities, milestones and highlighted achievements during the past 25 years of operation.

\begin{tabular}{|c|c|c|c|c|}
\hline $\begin{array}{l}\text { Awareness on } \\
\text { hemoglobinopathies }\end{array}$ & Advocacy work & Educational programs & Research projects & Collaborations \\
\hline $\begin{array}{l}\text { Thalassemia } \\
\text { International } \\
\text { Federation }\end{array}$ & $\begin{array}{l}\text { Delegation visits/field trips } \\
\text { to different countries }\end{array}$ & 15 training seminars & 6 major research projects & WHO \\
\hline $\begin{array}{l}\text { Official International } \\
\text { Thalassemia Day (May } 8^{\text {th }} \text { ) }\end{array}$ & $\begin{array}{l}\text { Positions papers: } \\
\text { Non-transfusion dependent } \\
\text { thalassemia }\end{array}$ & 55 national workshops & $\begin{array}{l}\text { Participation in } 25 \text { other } \\
\text { research projects }\end{array}$ & EU Council \\
\hline Quarterly magazine & Patients' rights - patients' safety & \multicolumn{2}{|l|}{10 regional conferences } & IAPO \\
\hline Bimonthly electronic newsletter & Chronic hepatitis C & \multicolumn{2}{|c|}{15 international scientific conferences } & ISBT \\
\hline Official active website & $\begin{array}{l}\text { Global patient community } \\
\text { Ribavirin for chronic hepatitis }\end{array}$ & \multicolumn{2}{|l|}{$\begin{array}{l}7 \text { booklets } \\
8 \text { publications } \\
1 \text { book } \\
\text { e-based Master of Science } \\
\text { Program at UCL }\end{array}$} & $\begin{array}{l}\text { ESTM } \\
\text { EPHA } \\
\text { Eurordis } \\
\text { IGA } \\
\text { Many other organizations }\end{array}$ \\
\hline
\end{tabular}

WHO, World Health Organization; EU, European Union; IAPO, International Alliance of Patient Organizations; ISBT, International Society of Blood Transfusion; ESTM, European School of Transfusion Medicine; EPHA, European Public Health Alliance; UCL, University College London; IGA, International Genetic Alliance. 
who volunteered devoting their life for a continuous struggle to support thalassemia patients and families to make their dream come true.

\section{The future}

No matter how significant the progress has been in the past, the struggle is still ongoing for the patients, families, and other stakeholders involved with hemoglobinopathies. There is still a great need to disseminate appropriate prevention and control strategies in every needy country at the national level, and live to celebrate the moment when all patients with hemoglobinopathies will enjoy equal access to quality health care across the world.

Furthermore, the medical and research community continues to face many challenges ahead. We need to advance our knowledge and understanding of the pathophysiology of different forms of hemoglobinopathies such as the thalassemia intermedia, and achieve a complete cure of this hereditary disease that would be accessible to every patient. Following a holistic approach, the international health organizations and donors' bodies are needed to continue their work in advancing recognition and prioritizing funds to achieve the development and implementation of sustainable prevention and control programs for hemoglobinopathies in every needy country. This is very timely considering the significant progress achieved in recent years in public health, communicable diseases and other health indicators including hereditary disorders in the vast majority of countries in a global scale.

\section{Conclusions}

TIF is celebrating its bronze birthdate having served global health on hemoglobinopathies for the past 25 years. TIF has succeeded in achieving many important milestones and continues to align its work with the WHO, the European Union, and other scientific and non-governmental organizations and supports global efforts not only in the field of thalassemia and hematological disorders but also in other relevant fields such as the emerging area of orphan drugs and rare diseases. TIF's work could serve as a highlighted global paradigm for other fields of public health so that others could follow its pathway and devel- op similar non-governmental federations, which will focus on specific health issues and complement the work of United Nations and the WHO in a coordinated successful fashion.

\section{References}

1. Angastiniotis M, Modell B. Global epidemiology of haemoglobin disorders. Ann N Y Acad Sci 1998;850:251-69.

2. Weatherall DJ. The inherited diseases of haemoglobin are an emerging global health burden. Blood 2010;115:4331-6.

3. Williams TN, Weatherall DJ. World distribution, population genetics, and health burden of the haemoglobinopathies. Cold Spring Harb Perspect Med 2012;2:a011692.

4. Weatherall DJ. Thalassemia as a global health problem; recent progress toward its control in the developing countries. Ann $\mathrm{N}$ Y Acad Sci 2010;1202:17-23.

5. Weatherall DJ, Clegg JB. The thalassaemia syndromes, 4th ed. 0xford: Blackwell Scientific Publications; 2001.

6. Angastiniotis M, Hadjiminas M. Prevention of thalasaemia in Cyprus. Lancet 1981;317:369-71.

7. Angastiniotis M, Kyriakidou S, Hadjiminas M. How thalassaemia was controlled in Cyprus. World Health Forum 1986;7:291-7.

8. Loukopoulos D. Haemoglobinopathies in Greece: prevention programme over the past 35 years. Indian J Med Res 2011; 134:572-6.

9. Ladis V, Karagiorga-Lagana M, Tsarta I, Chouliaras G. Thirty years experience in preventing haemoglobinopathies in Greece: achievements and potentials form optimization. Eur J Haematol 2013;90:31322.

10. Bianco I, Graziani B, Lerone M, et al. Prevention of thalassaemia major in Latium. Lancet 1985;2:888-9.

11. Amato A, Grisanti P, Lerone M, Ponzini D, et al. Prevention strategies for severe haemoglobinopathies in endemic and nonendemic immigration countries: the Latium experience. Prenat Diagn 2009; 29:1171-4.

12. Ostrowsky JT, Lippman A, Scriver CR. Cost-benefit analysis a thalassaemia disease prevention program. Am J Pub Health 1985;75:732-6.

13. WHO Working Group. Hereditary anemias: genetic basis, clinical features, diagnosis and treatment. WHO Bull 1982;60:643-60.

14. McAllister M, Dunn G, Payne K, et al. Patient empowerment: the need to consider it as a measurable patient-reported outcome for chronic conditions. BMC Health Serv Res 2012;12:157.

15. World Health Organization. EB118.R1 Thalassaemia and other haemoglobinopathies - Item 5.2 of the Agenda (Documents EB118/5 and EB118/5 Add.1). In: WHO, Executive Board, 118th Session, Geneva, 29-31 May 2006 - Resolutions and decisions, annexes, summary records. Geneva: World Health Organization; 2006. pp 63-64, 144-148. Available from: http://apps. who.int/gb/ebwha/pdf_files/EBSS-EB1182006-REC1/english/Res/res-eb118_2006_ rec1-en.pdf

16. World Health Assembly. WHA55.18, Agenda item 13.9 - Quality of care: patients safety, 18 May 2002. Geneva: World Health Assembly; 2002. pp 1-2. Available from: http:/www.who.int/medicines/areas/quality_safety/safety_efficacy/ewha5518.pdf

17. Eleftheriou A. Patient's rights. 2007. Thalassaemia International Federation Publication No. 7.

18. De Sanctis V, Soliman A, Angastiniotis M, et al. Highlights from the first thalassaemia forum on growth and endocrine complications in thalassaemia, Doha. Ped Endocrinol Rev 2012;9:552-9.

19. De Sanctis V, Soliman A, Elsedfy H, et al. Growth and endocrine disorders in thalassaemia: The international network on endocrine complications in thalassaemia (I-CET) position statement and guidelines. Indian J Endocrinol Metab 2013;17: 8-18.

20. Telfer P, Coen PG, Christou S, et al. Survival of medically treated thalassaemia patients in Cyprus. Trends and risk factors over the period 1980-2004. Haematologica 2006;91:1187-240.

21. Modell B, Khan M, Darlison M, et al. Improved survival of thalassaemia major in the UK and relation to $\mathrm{T} 2 *$ cardiovascular magnetic resonance. J Cardiovasc Magn Reson 2008;10:42.

22. Gollo G, Savioli G, Balocco M, et al. Changes in the quality of life of people with thalassaemia major between 2001 and 2009. Patient Prefer Adherence 2013;7:231-6. 